\begin{tabular}{lr}
\hline \multicolumn{1}{c}{ D Y N A M I C E C O N O M E T R I C } & M O D E L S \\
DOI: http://dx.doi.org/10.12775/DEM.2016.008 & Vol. 16 (2016) 145-164 \\
\hline $\begin{array}{l}\text { Submitted November 8, 2016 } \\
\text { Accepted December 21, 2016 }\end{array}$ & ISSN (online) 2450-7067 \\
ISSN (print) 1234-3862
\end{tabular}

Magdalena Osińska, Tadeusz, Kufel, Marcin Błażejowski, Pawet Kufel

\title{
Modelling and Forecasting Business Cycle in CEE Countries using a Threshold Approach ${ }^{* *}$
}

\begin{abstract}
A b s t r a c t. We propose to apply a time-series-based nonlinear mechanism in the threshold autoregression (TAR) form in order to examine business cycles in Central and Eastern European economies and compare them to the entire EU business cycle. The threshold variables, such as consumer price index, short and long interest rates, unemployment rate and an exchange rate vs. the U.S. Dollar, have been considered. The purpose of the paper is to model and to predict business cycles in Central and East European (CEE) economies (the EU Member States) and compare them to business cycles of the entire EU28 area and Eurozone EU19. We found that the exogenous mechanism played an important role in diagnosing the phases of business cycles in CEE economies, which is in line with the entire EU economic area. The results of business cycle forecasting using bootstrap technique are quite promising, while bootstrap confidence intervals are used for diagnosis.
\end{abstract}

K e y w o r d s: business cycle, central and eastern economies, threshold models, forecasting, bootstrap

J E L Classification: C24, C53, E32.

\footnotetext{
* Correspondence to: Magdalena Osińska, Nicolaus Copernicus University, Faculty of Economic Sciences and Management, 11A Gagarina Street, 87-100 Toruń, Poland, e-mail: emo@umk.pl; Tadeusz Kufel, Nicolaus Copernicus University, Faculty of Economic Sciences and Management, 11A Gagarina Street, 87-100 Toruń, Poland, e-mail: tadeusz.kufel@umk.pl; Marcin Błażejowski, WSB University in Toruń, e-mail: marcin.blazejowski@wsb.torun.pl; Paweł Kufel, WSB University in Toruń, e-mail: pawel.kufel@wsb.torun.pl.

${ }^{* *}$ This work was financed from National Center of Science - Grant No 2012/07/B/HS4/02927.

(C) 2016 Nicolaus Copernicus University. All rights reserved.

http://www.dem.umk.pl/dem
} 


\section{Introduction}

The purpose of the paper is to model and predict a business cycle in Central and East European (CEE) economies (the EU Member States) and to compare it to the business cycle of the entire EU28 area and Eurozone EU19. Our analysis is based on the theory of economic convergence, introduced by Barro, Sala-i-Martin (1992); however, newest empirical facts resulting from the economic crisis of the recent years have been taken into consideration, too. For at least two last decades, it has been assumed that Central and Eastern European Economies have undergone the process of catching up with the most developed Western European Economies. Since 2004 (as well as before), huge structural funds have been spent to speed up the entire process of economic unification of the EU area. Common currency - the Euro - has become one of the symbols of the unification. At present, 19 of 28 economies use this currency, eliminating one of the internal risk factors but exposing themselves to the external ones. However, the economic crisis of 2007-2009 has broken the process of economic convergence and reveals many differences among the countries. It is worth noting that, after 2004, Central and East European (CEE) countries usually experienced a sigma-type convergence and a conditional beta-type convergence (see Kluth, 2016).

In recent literature, two important issues can be found. The first is related to the problem of economic convergence and divergence (decoupling). The hypothesis of decoupling between business cycles in the developed and emerging countries after 2009 has become the subject of a widespread academic debate. In their paper, Claassen, Kabundi, Loots (2013) stated that decoupling between advanced and emerging economies took place, but in recent years the process of re-coupling has started. Kawa (2013) demonstrated that regardless the fact that many CEE countries introduced the defense mechanisms against the shocks to their regulation systems in the 90s, they remain vulnerable to the external debt, budget deficit and foreign trade imbalance. Stańczyk, Wyrobek (2013) have analyzed the issue of business cycle synchronization between the USA and emerging economies in 19952009. The authors concluded that no evidence was found that emerging economies as a whole and in subgroups had their business cycles synchronized. However, cycles in many emerging economies were more synchronized with the US economy, particularly at the time of the global economic crisis. They also stated that unexpected and unusual phenomena like global crises, disrupted the relationships among the economies observed in a "normal" state of development. 
The second issue - more recent and yet more open to questions - is focused on the problem of the so-called "middle-income trap". Our choice of the Central and Eastern Economies has been motivated by the fact that they are threatened by what has become known as the middle-income trap. This means that compared to the richest economies, their per-capita income stays low and there is little chance to overcome this difficulty. Spence (2011) refers to the middle-income countries as to those in the 5,000-10,000 USD range of per capita income. He indicates that in developing countries "the industries that drove the growth in the early period start to become globally uncompetitive due to rising wages". Among the CEE countries, only Bulgaria and Romania entered this range in 2015. The countries analyzed in-depth in the paper have their GDP per capita above 10,000 USD, but some of them, particularly Poland, Hungary and Slovakia, are not very far from this limit. The concept of middle-income trap is still a subject of the economic debate. Recently, it has been widely discussed in Im, Rossenblatt (2015). If the middle-income trap is what the developing European economies are trying to avoid, they should speed up the catching up process by undertaking intensive reforms. That is why the business cycle forecasts must be taken into account.

Our research is a part of a bigger project and it has been preceded by earlier reports. Osińska, Kufel, Błażejowski, Kufel (2016a) have examined the business cycles synchronization within the EU economies in comparison to the U.S. and Japan, using spectral analysis methodology. Both the quarterly and monthly data has been analyzed, supporting the same results. They found that most European countries, including the CEE countries, had their economic cycles synchronized with the entire EU. Only Hungary represented the opposite case. As for the U.S.A. and Japanese business cycles, the two were more synchronized together compared with the EU. In the paper by Osińska, Kufel, Błażejowski, Kufel (2015), a business cycle clock methodology for the same economies has been applied. In the paper by Osińska, Kufel, Błażejowski, Kufel (2016b) the threshold autoregression models (TAR) has been applied to reveal the most likely threshold mechanisms, which underlie the business cycles in the EU economies. The concept that debt/GDP ratio could be the indicator of the changes between the business cycle phases, has been rejected.

In the reported research, the quarterly data of 1995-2014 were analyzed. The gross domestic product (GDP) growth rate was traditionally used as the business cycle measure. The following research questions have been formed: which threshold variable(s) help to reveal a threshold mechanism within the business cycles observed in Central and Eastern European economies; what 
is the scope of differences between the regimes, what is the forecasting ability of the estimated TAR models and what similarities/differences between the observed countries can be indicated. The methodology assumes using a stationary TAR model as the basis for applying bootstrap technique. The threshold variable prediction was a key factor in the entire procedure. Bootstrap confidence intervals have been used for ex ante forecast evaluation. The novelty of the paper lies in defining a simulation-based procedure for forecasting TAR models and its application to the business cycle in CEE countries.

The paper is organized as follows: in Section two, the data has been analyzed from both perspectives: the economic convergence process and business cycle analysis; in Section three, the research methodology has been described. In Section four, the empirical results have been presented. In Section five the conclusion is summarised.

\section{Characteristics of the Data}

One of the most popular perspectives of classification of economies is based on the criterion of initial wealth measured by the GDP per inhabitant. The initial wealth is crucial for understanding the individual process of economic development and the final stage proves the convergence of a given economy along its long-run path. As it has been already mentioned, the process of catching up may be slowed down while the country experiences the middleincome trap. The new EU Member States that belong to the Central and Eastern European group are Bulgaria, The Czech Republic, Estonia, Croatia, Hungary, Lithuania, Latvia, Poland, Romania, the Slovak Republic and Slovenia. In the beginning of the analyzed period i.e., in 1995, all these countries had their GDP per inhabitant below 10,000 USD, while in 2015 only Bulgaria and Romania had the GDP per capita remaining below this limit. In the same year, Slovenia's GDP, with its 20,713.1 USD (in current prices), surpassed Portugal and Greece, where both countries were included in the group EU15. This means that some of the newest EU Member States that acceded the EU in 2004, managed to make a successful progress in the process of economic convergence, measured by the dispersion from the average level. This process was broken by the recession of 2007-2009, when each country was faced with its own economic decisions being more or less in line with the EU economic policy (Osińska and Kluth, 2011). Countries like Poland and Hungary, with their GDP p.c. equal to 12,494.5 USD and 12,259.1 USD, respectively, may be concerned about the middle-income trap unless the structure of the productive sectors of the economies will change. 
Slovakia with the GDP p.c. of 15,962.6 USD, seems to be more resistant and similar to the Czech Republic and Estonia, where the GDP p.c. exceeds 17,000 USD.

The study uses quarterly data from 1995-2014, taken from the OECD database study. In several cases, some data were not complete, therefore, we decided to limit our investigation to the countries where databases were as broad as possible. Thus, the following countries have been examined: the Czech Republic, Estonia, Hungary, Poland, Slovakia and Slovenia. The mechanism of the creation of economic cycle in these countries has been the subject of comparison with both the entire EU28 and the entire Eurozone EA19.

The figure 1 shows the business cycle dynamics for three selected countries and the EU28.
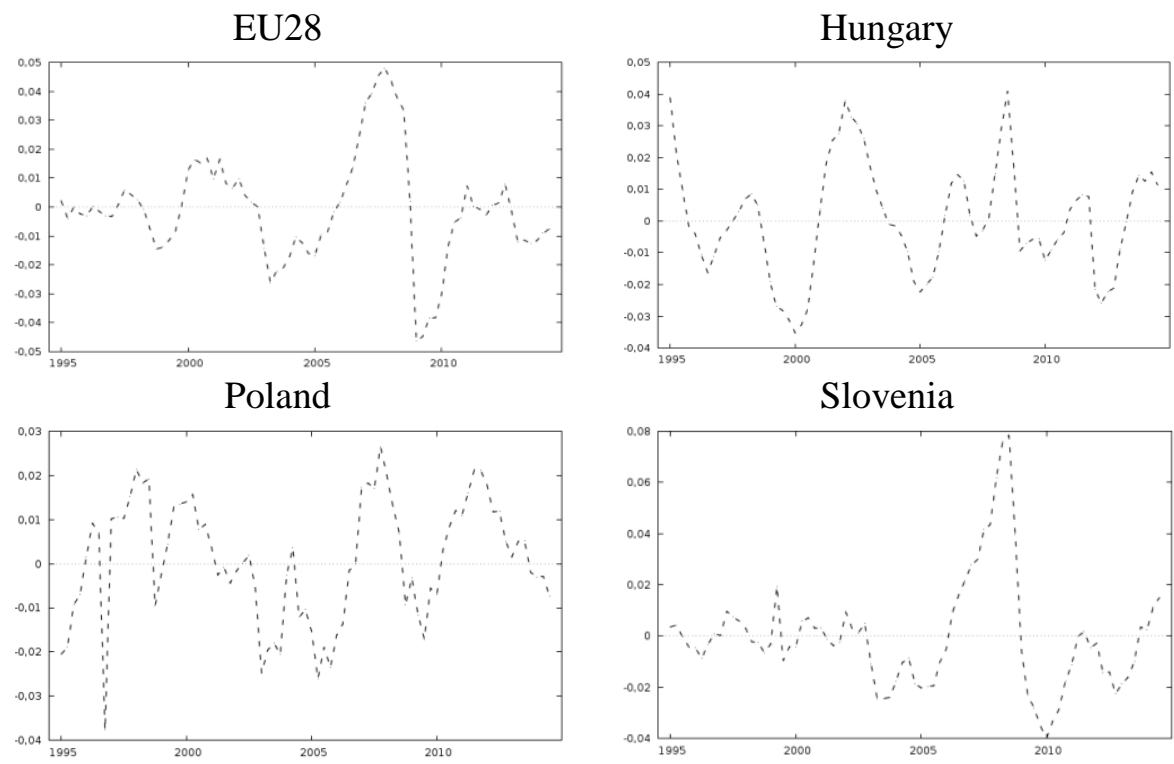

Figure 1. Business cycles in selected CEE countries and in the EU28

The original GDP series (seasonally adjusted) has been transformed for extracting a business cycle by taking logs and filtering by the HodrickPrescott filter with the smoothing parameter equal to 1,600 (Hodrick, Prescott, 1997). In Figure 1, the differences among selected countries, considering the amplitude and phase of the cycle, can be noticed.

In the threshold autoregression (TAR) models, the assumption of threshold variable is of key importance. In our study, we assumed that the set of 
exogenous thresholds consists of the following: the consumer price index, short interest rate, long interest rate, unemployment rate and exchange rate. The choice of variables has been determined by data availability and their relation to business cycle analysis. It can be mentioned that when compared to the reference variable, namely the GDP growth rate, the CPI and long interest rate are considered as exhibiting the same changes over time, while the short interest rate and exchange rate are leading indicators for the cycle. The reaction of the unemployment rate usually lags behind. These assumptions are empirically verified; however, they may differ among the countries (Zarnowitz, 1999).

All these series were checked for stationarity using the ADF/KPSS approach and finally they were taken at both levels $(\mathrm{I}(1))$ and $(\mathrm{I}(0))$.

\section{The Model and Forecasting Procedure}

The threshold autoregression models have been applied to the U.S. business cycle modeling by Tong (Tong, 1990). Recently, their particular assessment of economic growth has been determined in the publications such as by and Niebuhr, 2005 who shed the light on the regional perspective of growth in Germany and al., 2013, who introduced a dynamic panel threshold model to estimate inflation thresholds for a long-term economic growth, to mention only a few. In our research, TAR models have been used as well because that allows considering different threshold variables as playing a possible rule in regime changes.

When the lagged endogenous variable is a threshold variable, the model is known as a self-exciting threshold autoregression (SETAR). This difference allows identifying exogenous or endogenous mechanism of changes between the regimes that correspond to business cycle phases. This interpretation coincides with the endogenous and exogenous growth idea in economics.

Let $Y_{t}$ denotes $k$-dimensional random vector. The model of the following form:

$$
Y_{t}=B^{J_{t}} Y_{t}+A^{J_{t}} Y_{t-1}+H^{J_{t}} \varepsilon_{t}+C^{J_{t}},
$$

where $J_{t}$ is a random variable taking values of finite set of natural numbers $\{1,2,3, \ldots, p\}, B^{J_{t}}, A^{J_{t}}, H^{J_{t}}$ are $k \times k$ - dimensional matrices of the coefficients, $\varepsilon_{t}$ is the $k$-dimensional white noise, $C^{J_{t}}$ is a constant vector is called a canonical form of the threshold model. It defines a wide class of the models depending on the choice of $J_{t}$. 
When $J_{t}$ is the function of an exogenous variable, say, $X_{t}$ $\left(X_{t} \in\left\{X_{i t}\right\}, i=1, \ldots, m\right)$ then we obtain a TAR model. The $\operatorname{TAR}\left(p ; k_{1}, k_{2}, \ldots, k_{p}\right)$ model is defined in the following way:

$$
Y_{t}=\alpha_{0}^{j}+\sum_{i=1}^{k_{j}} \alpha_{i}^{j} Y_{t-i}+h^{j} \varepsilon_{t}
$$

conditionally on $X_{t-d} \in R_{j}, j=1, \ldots, p$. The $X_{t-d}$ is called a threshold variable. The more convenient form of presenting (2) is as follows:

$$
Y_{t}= \begin{cases}\alpha_{0}^{1}+\alpha_{1}^{1} Y_{t-1}+\ldots+\alpha_{k_{1}}^{1} Y_{t-k_{1}}+h^{1} \varepsilon_{t} & \text { for } X_{t-d} \leq r_{1} \\ \alpha_{0}^{2}+\alpha_{1}^{2} Y_{t-1}+\ldots+\alpha_{k_{2}}^{2} Y_{t-k_{2}}+h^{2} \varepsilon_{t} & \text { for } r_{1}<X_{t-d} \leq r_{2} \\ \cdots & \\ \alpha_{0}^{p}+\alpha_{1}^{p} Y_{t-1}+\ldots+\alpha_{k_{p}}^{p} Y_{t-k_{p}}+h^{p} \varepsilon_{t} & \text { for } X_{t-d}>r_{p-1}\end{cases}
$$

In a SETAR model the threshold variable is lagged endogenous variable namely, $Y_{t}$. It is useful to present the two regimes model with the $\mathrm{I}(\mathrm{x})$ function of the form:

$$
I(x)= \begin{cases}0 & \text { when } x_{t-d} \leq 0 \\ 1 & \text { when } x_{t-d}>0\end{cases}
$$

and the corresponding $\operatorname{TAR}(2, \mathrm{k} 1, \mathrm{k} 2)$ model

$$
\begin{aligned}
& Y_{t}=\left(\alpha_{0}+\alpha_{1} Y_{t-1}+\ldots+\alpha_{k 1} Y_{t-k 1}\right)+ \\
& \left(\beta_{0}+\beta_{1} Y_{t-1}+\ldots+\beta_{k 2} Y_{t-k 2}\right) \cdot I\left(X_{t-d}\right)+\varepsilon_{t}
\end{aligned} .
$$

If all $\beta_{0}, \beta_{1}, \ldots, \beta_{k}$ parameters are zeros then (5) becomes the linear autoregressive model. When the autoregressive model is considered, its stationarity becomes the crucial point. For the linear autoregressive model, the conditions of stationarity are well known and easy to satisfy (see: Greene, 1993). In the case of SETAR or TAR, the problem is much more complicated. Even stationary models within the regimes do not guarantee the stationarity of the whole system. Giordano, Niglio and Vitale (2012) analyzed this problem, basing it on the papers by Petruccelli and Woolford (1984) and Chan et al. (1985).

In the case of two regime SETAR model (3) when $k$ is greater than 1, the following stationarity conditions must be satisfied (An, Huang, 1996; Lin, 1999): 


$$
\begin{aligned}
& \max _{j} \sum_{i=1}^{k}\left|a_{i}^{(j)}\right|<1 \\
& \sum_{i=1}^{k} \max _{j}\left|a_{i}^{(j)}\right|<1 .
\end{aligned}
$$

Estimation of TAR/SETAR models can be done by conditional ordinary least squares or maximum likelihood methods. However, the forecasting is more complex. First of all, it is important to determine the predicted values of the threshold variable in the forecasting possibility. For this reason, we started our procedure for the TAR models first because they underlay the exogenous threshold mechanism.

Our proposal consists of the application of a simulation methodology for forecasting both: the threshold variable $X_{t-d}$ as well as the endogenous variable $Y_{t}$, which is the which is the business cycle (as presented in Figure 1). The idea of forecasting TAR models has been developed by Brown and Mariano (1984). Forecasting procedure proposed and applied in this paper has been presented in Gretl environment (Threshold_Models package). It is based on the already-estimated TAR model and it is implemented in one of the two common simulation approaches, i.e., the bootstrap simulation technique (see Dvison et al., 1986) or Monte Carlo method (see Rubinstein and Kroese, 2011). A simulation-based forecasting procedure applies to both endogenous and threshold variables, but the starting point is to simulate the possible paths of the threshold variable. The whole procedure is carried out in the following steps:

1. Estimation of the predictive model for the threshold variable. The SARIMA $(p, d, q)(P, D, Q)$ approach with the specification selection based on the Schwarz information criterion (BIC) is applied.

2. Generating a noise for the simulation procedure:

- when in the bootstrap approach, residuals from estimated SARIMA model are used (empirical distribution),

- when in the Monte Carlo approach, random numbers are drawn from one of the theoretical distributions, i.e., normal or t-Student with a mean of zero and a standard deviation equal to the value from the estimated SARIMA model.

3. Addition of Phase Noise to the values of threshold variable, reestimation of the SARIMA model and prediction of the threshold variable for $h$ periods ahead. 
4. Determination of regimes in which the endogenous variable will be in the future (on the basis of the threshold variable forecasts generated in the previous stage).

5. Usage of the already-estimated TAR model to generate forecasts of the endogenous variable.

6. Stages $2-5$ are repeated $N$ times.

\section{The Empirical Results}

The following quarterly data from 1995-2014 are included and have been analyzed (short names are given in brackets): the GDP growth rate (GDP), unemployment rate (UEMP), interest rates (long IR and short IR), CPI and first differences of CPI, exchange rates in USD (EXR) and its first differences. It was assumed that the GDP growth rate was the endogenous variable and the remaining lagged variables were supposed to be thresholds for regime changes. The regimes correspond to the phases of economic cycle. To eliminate non-stationarity, the original GDP series were de-trended using HP filter where $\lambda=1600$.

All the original data were seasonally adjusted, transformed into logs and tested for stationarity using ADF-GLS and KPSS tests. The number of regimes was restricted to maximum three for the following reasons: the relatively short time series and reasonable interpretation of the business cycle in case of prosperity, recession and the intermediary states of increasing and decreasing of the GDP. The number of regimes has been chosen based on the quartiles of the threshold variable. In practice, the following model has been considered:

$$
G D P_{t}=\left\{\begin{array}{cc}
\alpha_{0}^{1}+\alpha_{1}^{1} G D P_{t-1}+\cdots+\alpha_{k_{1}}^{1} G D P_{t-k_{1}}+\varepsilon_{t} & \text { for } X_{t-d}<r_{1} \\
\alpha_{0}^{2}+\alpha_{1}^{2} G D P_{t-1}+\cdots+\alpha_{k_{2}}^{2} G D P_{t-k_{2}}+\varepsilon_{t} & \text { for } r_{1}<X_{t-d}<r_{2} \\
\alpha_{0}^{3}+\alpha_{1}^{3} G D P_{t-1}+\cdots+\alpha_{k_{3}}^{3} G D P_{t-k_{3}}+\varepsilon_{t} & \text { for } X_{t-d}>r_{2}
\end{array}\right.
$$

where a set of threshold variables $X_{t-d}$ is the same as it was described at the beginning of this section. As many threshold models were to be estimated we decided to use Bayesian Information Criterion (BIC) for the model selection. The results of model selection are presented in Tables 1,2 and 3. 
Table 1: Values of Schwartz criterion and threshold values for Czech Republic, Estonia and Hungary

\begin{tabular}{|c|c|c|c|c|c|c|}
\hline & \multicolumn{2}{|c|}{ Czech Rep. } & \multicolumn{2}{|c|}{ Estonia } & \multicolumn{2}{|c|}{ Hungary } \\
\hline & $\mathrm{BIC}$ & threshold & $\mathrm{BIC}$ & threshold & $\mathrm{BIC}$ & threshold \\
\hline EXR & $-522,202$ & 20,314 & & & $-558,056$ & 176,364 \\
\hline d_EXR & $-520,460$ & $-0,042$ & & & $-540,131$ & $-0,032$ \\
\hline$\overline{\mathrm{CPI}}$ & $-522,902$ & 1,757 & $-307,094$ & 3,057 & $-544,147$ & 6,906 \\
\hline d_CPI & $-527,509$ & $-0,018$ & $-292,824$ & $-0,02 \quad 0,020$ & $-542,474$ & $-0,01 \quad 0,010$ \\
\hline longIR & $-372,092$ & 3,502 & & & $-395,920$ & 7,469 \\
\hline d_longIR & $-374,295$ & $-0,001$ & & & $-392,023$ & $-0,001$ \\
\hline shortlR & $-522,206$ & 3,843 & $-364,478$ & 3,968 & & \\
\hline d_shortlR & $-519,079$ & $-0,001$ & $-344,437$ & $-0,004$ & & \\
\hline UNEMP & $-416,655$ & 7,283 & $-265,276$ & 7,474 & $-409,457$ & 7,382 \\
\hline d UNEMP & $-408,035$ & $-0,245$ & $-270,077$ & $-0,89 \quad 0,383$ & $-398,233$ & 0,040 \\
\hline SETAR & $-522,752$ & $-0,005$ & $-371,486$ & $-0,002$ & $-525,239$ & $-0,001$ \\
\hline sd_EXR & $-469,528$ & 26,594 & & & $-456,666$ & 174,182 \\
\hline sd_d_EXR & $-471,243$ & $-0,012$ & & & $-450,686$ & 0,015 \\
\hline sd_CPI & $-469,097$ & $1,757 \quad 7,689$ & $-272,050$ & 3,057 & $-453,485$ & 6,906 \\
\hline sd_d_CPI & $-472,006$ & $-0,018$ & $-250,539$ & $-0,020$ & $-450,934$ & $-0,012$ \\
\hline sd_longIR & $-355,049$ & 4,193 & & & $-351,032$ & 6,807 \\
\hline sd_d_longIR & $-346,873$ & $-0,003$ & & & $-341,508$ & $-0,001$ \\
\hline sd_shortlR & $-475,691$ & $2,090 \quad 9,762$ & $-314,583$ & $3,955 \quad 6,359$ & & \\
\hline sd_d_shortlR & $-477,825$ & $-0,004$ & $-301,225$ & $-0,001$ & & \\
\hline sd_UNEMP & $-392,193$ & 6,709 & $-225,906$ & 10,154 & $-359,549$ & 7,400 \\
\hline sd_d_UNEMP & $-382,344$ & $-0,245$ & $-224,844$ & $-0,140$ & $-350,690$ & 0,040 \\
\hline Sd_SETAR & $-464,230$ & $-0,023$ & $-309,123$ & $-0,016$ & $-438,251$ & $-0,001$ \\
\hline
\end{tabular}

Note: BIC - value of Schwarz criterion, treshold - value of threshold (if one value is given means model with 2 regimes, if 2 values id given means model with 3 regimes), the best value of BIC for each country has been bolded, $d_{-}$- means first differences, sd_- means seasonal differences.

Empirical analysis of business cycles in CEE countries has revealed the most likely threshold variables in the countries in terms of interest. These are: the CPI in the case of Slovenia and $\triangle \mathrm{CPI}$ in the case of the Czech Republic, a short interest rate in the case of Estonia and the exchange rate against the USD for the other four cases, i.e., Hungary, Poland, the EU28 and the EU19. In the case of Slovak Republic, the difference in the exchange rate has been indicated. It shows the importance of the exchange rate channel in the risk exposure of such economic bodies as the European Union and its Member States. The two other countries were more sensitive to the consumer price changes and the last one, namely, Estonia, to the monetary policy changes. Obviously, the statistical identification of the thresholds may be limited by the availability of data, but the most likely differences for the mechanism change within similar economic system area is interesting. The level of economic development of particular EU countries remains still diversified and determines the expected results. For these reasons, we assumed the same set 
of threshold variables that were the subject of testing for the GDP growth rate. Tables 4 and 5 present the estimated TAR models for selected thresholds.

Table 2: Values of Schwartz criterion and threshold values for Poland, Slovak Republic, Estonia and Slovenia

\begin{tabular}{|c|c|c|c|c|c|c|}
\hline & \multicolumn{2}{|c|}{ Poland } & \multicolumn{2}{|c|}{ Slovak Rep. } & \multicolumn{2}{|c|}{ Slovenia } \\
\hline & $\mathrm{BIC}$ & threshold & $\mathrm{BIC}$ & threshold & $\mathrm{BIC}$ & threshold \\
\hline EXR & $-498,012$ & 2,772 & $-449,867$ & 0,759 & $-502,767$ & $0,763 \quad 0,803$ \\
\hline d_EXR & $-493,983$ & 0,006 & $-457,259$ & $-0,009$ & $-509,749$ & $-0,03 \quad-0,01$ \\
\hline$\overline{\mathrm{CPI}}$ & $-491,671$ & 4,224 & $-447,620$ & 2,882 & $-519,869$ & 5,641 \\
\hline d_CPI & $-492,383$ & $-0,035$ & $-451,712$ & $-0,01 \quad 0,014$ & $-500,665$ & $-0,018$ \\
\hline longlR & $-357,629$ & 5,750 & $-306,867$ & 4,640 & $-291,729$ & 4,647 \\
\hline d_longIR & $-357,032$ & $-0,004$ & $-273,577$ & $-0,001$ & $-294,096$ & $-0,001$ \\
\hline shortIR & $-492,587$ & $4,590 \quad 20,660$ & & & $-312,699$ & $3,697 \quad 4,728$ \\
\hline d_shortlR & $-500,652$ & $-0,013$ & & & $-294,841$ & 0,000 \\
\hline UNNEMP & $-491,760$ & 13,031 & $-444,902$ & 12,354 & $-378,125$ & 6,025 \\
\hline d_UNEMP & $-490,523$ & $-0,410$ & $-439,242$ & $-0,392$ & $-382,968$ & $-0,256$ \\
\hline SETAR & $-480,468$ & 0,002 & $-450,458$ & $-0,004$ & $-475,356$ & $-0,003$ \\
\hline sd_EXR & $-423,530$ & $3,175 \quad 3,824$ & $-400,520$ & 0,762 & $-422,020$ & 0,800 \\
\hline sd_d_EXR & $-426,900$ & $-0,023$ & $-389,912$ & $-0,032$ & $-416,761$ & $-0,007$ \\
\hline sd_CPI & $-421,851$ & $2,084 \quad 13,050$ & $-388,697$ & $3,009 \quad 5,655$ & $-416,292$ & 6,562 \\
\hline sd_d__CPI & $-428,644$ & $-0,036$ & $-389,507$ & $-0,030$ & $-425,120$ & $-0,008$ \\
\hline sd_longlR & $-309,168$ & 5,232 & $-255,755$ & 4,640 & $-264,005$ & 4,647 \\
\hline sd_d_longlR & $-307,192$ & $-0,004$ & $-253,535$ & $-0,001 \quad 0,002$ & $-259,146$ & $-0,004$ \\
\hline sd_shortlR & $-436,382$ & $6,883 \quad 21,770$ & & & $-265,775$ & 3,697 \\
\hline sd_d_shorttR & $-425,519$ & $-0,012$ & & & $-267,981$ & $-0,003$ \\
\hline sd ÜNEMP & $-423,913$ & 10,022 & $-389,320$ & 12,377 & $-333,151$ & 6,025 \\
\hline sd_d_UNEMP & $-422,224$ & $-0,410$ & $-388,072$ & $-0,099$ & $-325,931$ & $-0,256$ \\
\hline sd_SETAR & $-412,556$ & $-0,013$ & $-381,351$ & $-0,010$ & $-397,089$ & 0,004 \\
\hline
\end{tabular}

Note: BIC - value of Schwarz criterion, treshold - value of threshold (if one value is given means model with 2 regimes, if 2 values id given means model with 3 regimes), the best value of BIC for each country has been bolded, $d_{-}-$means first differences, sd_- means seasonal differences.

Only in one case, i.e., the EU28, a three-regime model has been selected. In the other cases, two-regime models have been preferred for the data. Figure 2 illustrates the "goodness-to-fit" calculator of the empirical TAR model. which is very good in all cases. 
Table 3: Values of Schwartz criterion and threshold values for European Union and Euro Area

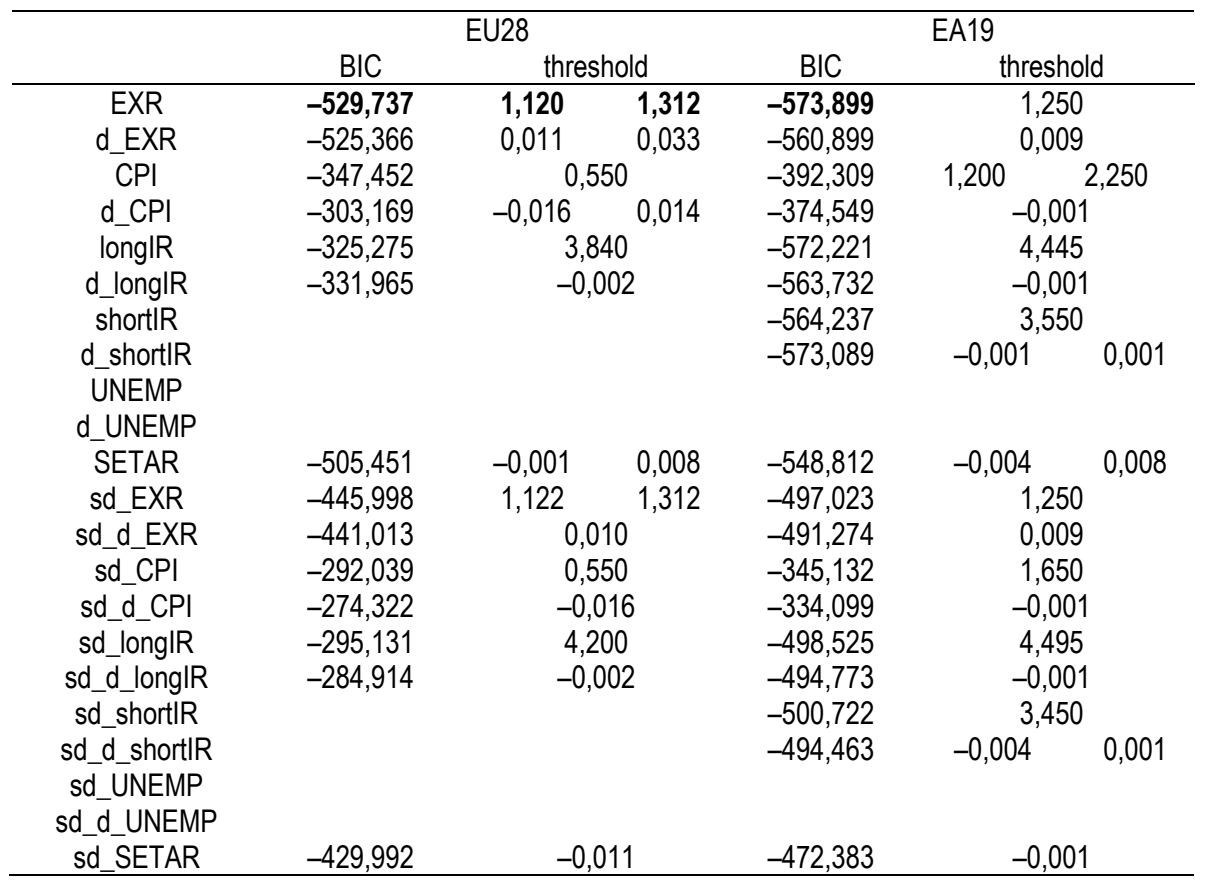

Note: BIC - value of Schwarz criterion, treshold - value of threshold (if one value is given means model with 2 regimes, if 2 values id given means model with 3 regimes), the best value of BIC for each country has been bolded, $d_{-}$- means first differences, $\mathrm{sd}_{-}$- means seasonal differences.

Table 4: Estimated threshold models with lowest BIC values for Czech Rep., Estonia, Hungary and Poland

\begin{tabular}{|c|c|c|c|c|}
\hline & $\begin{array}{l}\text { Czech Rep. } \\
\text { d_CPI (-4) }\end{array}$ & $\begin{array}{c}\text { Estonia } \\
\text { shorttR }(-3)\end{array}$ & $\begin{array}{l}\text { Hungary } \\
\operatorname{EXR}(-3)\end{array}$ & $\begin{array}{c}\text { Poland } \\
\text { EXR }(-3)\end{array}$ \\
\hline r1 const & $-0,006^{* * *}$ & 0,002 & $-0,002$ & $-0,003$ \\
\hline $\mathrm{r} 1 \mathrm{Y}_{\mathrm{t}-1}$ & $1,133^{* * *}$ & $0,518^{* * *}$ & $0,61^{* * *}$ & 0,167 \\
\hline $\mathrm{r} 1 \mathrm{Y}_{\mathrm{t}-2}$ & $-0,533^{\star * *}$ & $0,898^{\star * *}$ & & \\
\hline$r 1 Y_{t-3}$ & & $-0,016$ & & \\
\hline $\mathrm{r} 1 \mathrm{Y}_{\mathrm{t}-4}$ & & $-0,539^{* * *}$ & & \\
\hline r2 const & 0,001 & $-0,005^{*}$ & 0,000 & 0,001 \\
\hline $\mathrm{r} 2 \mathrm{Y}_{\mathrm{t}-1}$ & $1,313^{\star \star *}$ & $0,951^{\star * *}$ & $1,312^{\star * *}$ & $0,841^{* \star *}$ \\
\hline $\mathrm{r} 2 \mathrm{Y}_{\mathrm{t}-2}$ & $-0,413^{* * *}$ & $0,294^{*}$ & $-0,175$ & \\
\hline $\mathrm{r} 2 \mathrm{Y}_{\mathrm{t}-3}$ & 0,091 & $-0,476^{* * *}$ & $-0,34^{* * *}$ & \\
\hline$r 2 Y_{t-4}$ & $-0,025$ & & & \\
\hline $\mathrm{r} 2 \mathrm{Y}_{\mathrm{t}-5}$ & $-0,177^{\star * *}$ & & & \\
\hline
\end{tabular}

Note: $* * *-1 \%$ significance level, $* *-5 \%$ significance level, $*-10 \%$ significance level, $\mathrm{r} 1$ means regime $1, \mathrm{r} 2$ - regime $2, \mathrm{r} 3$ - regime 3 .

Dynamic EConometric Models 16 (2016) 145-164 
Table 5: Estimated threshold models with lowest BIC values for Slovak Rep., Slovenia, European Union and Euro Area.

\begin{tabular}{rcccc}
\hline & $\begin{array}{c}\text { Slovak Rep. } \\
\text { d_EXR(-1) }\end{array}$ & $\begin{array}{c}\text { Slovenia } \\
\text { CPI }(-2)\end{array}$ & $\begin{array}{c}\text { European Union } \\
\text { EXR }(-5)\end{array}$ & $\begin{array}{c}\text { Euro Area } \\
\text { EXR(-2) }\end{array}$ \\
\hline r1 const & 0,002 & 0,001 & 0,000 & $-0,001$ \\
r1 $Y_{t-1}$ & $0,931^{* * *}$ & $1,13^{* * *}$ & $1,398^{* * *}$ & $0,866^{* * *}$ \\
r1 $Y_{t-2}$ & & 0,181 & $-0,539^{* * *}$ & \\
r1 $Y_{t-3}$ & & $-0,178$ & & \\
r1 $Y_{t-4}$ & & $-0,195^{* *}$ & & \\
\hline r2 const & $-0,004$ & $-0,001$ & 0,001 & 0,000 \\
r2 $Y_{t-1}$ & $0,525^{* * *}$ & $0,587^{* * *}$ & $1,663^{* * *}$ & $1,45^{* * *}$ \\
r2 $Y_{t-2}$ & & & $-0,729^{* * *}$ & $-0,626^{* * *}$ \\
r2 $Y_{t-3}$ & & & & \\
r2 $Y_{t-4}$ & & & & \\
r2 $Y_{t-5}$ & & & $-0,004^{* * *}$ & \\
\hline 2 const & & & $1,277^{* * *}$ & \\
r3 $Y_{t-1}$ & & & $-0,883^{* * *}$ & \\
r3 $Y_{t-2}$ & & & $0,548^{* * *}$ & \\
r3 $Y_{t-3}$ & & & $-0,342^{* * *}$ & \\
r3 $Y_{t-4}$ & & & \\
\hline
\end{tabular}

Note: $* * *-1 \%$ significance level, $* *-5 \%$ significance level, $*-10 \%$ significance level, $\mathrm{r} 1$ means regime $1, \mathrm{r} 2$ - regime $2, \mathrm{r} 3$ - regime 3 .

Czech Republic

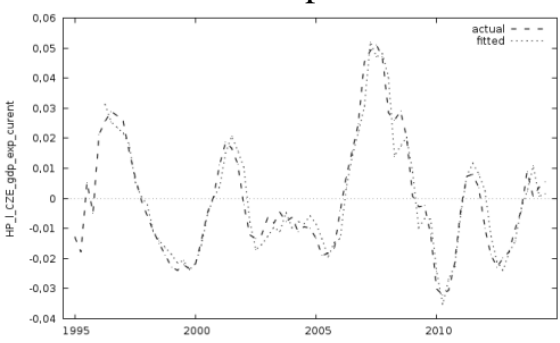

UE28

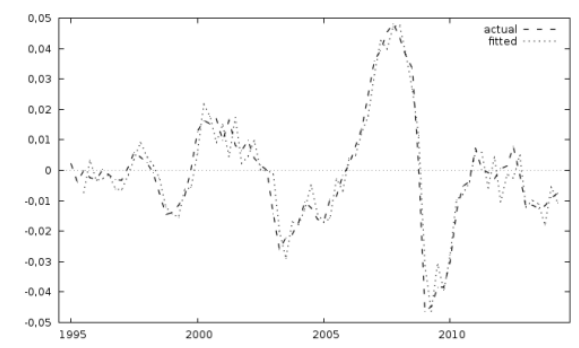

Figure 2. Actual and fitted (based on TAR model) values of business cycle in Czech Republic and EU28

Business cycle prediction was the next step of the analysis. According to the procedure described in Section 3, we used bootstrap technique for both forecasting the threshold variable and forecasting the business cycle using 1,000 replications. The results of forecasting both the threshold variables indicated in Table 1 and the endogenous variable, are shown in Figure 3. Two cases have been omitted. The first is the case of the Slovak Republic, where the exchange rate difference serves as a threshold. The bootstrap forecasts for this variable are stable over a certain constant, thus the forecasts cannot be 
interpreted properly. The second case, the Eurozone (EU19), is pretty similar to the EU28.

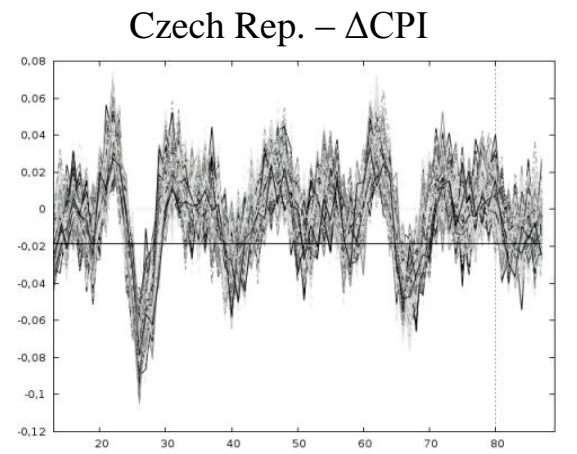

Estonia - short IR

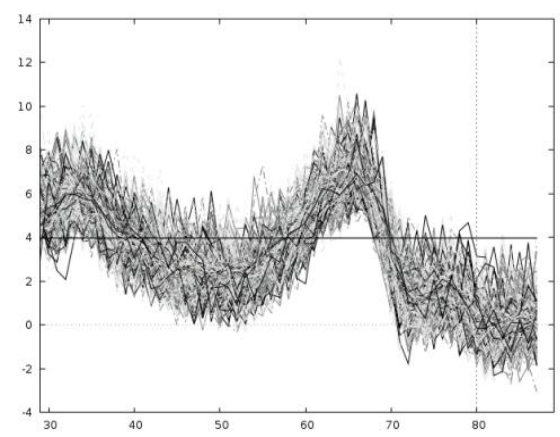

Hungary - HUF/USD

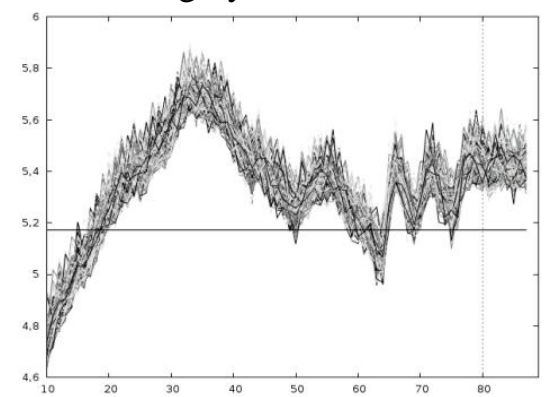

Czech Rep. - bootstrap forecast

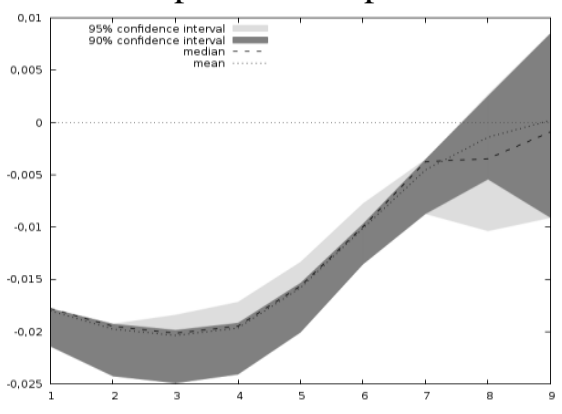

Estonia - bootstrap forecast

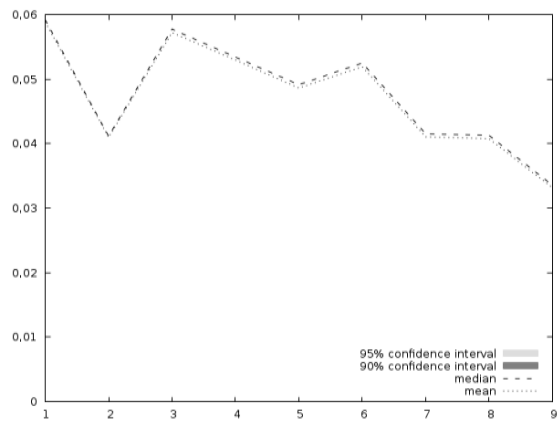

Hungary - bootstrap forecast

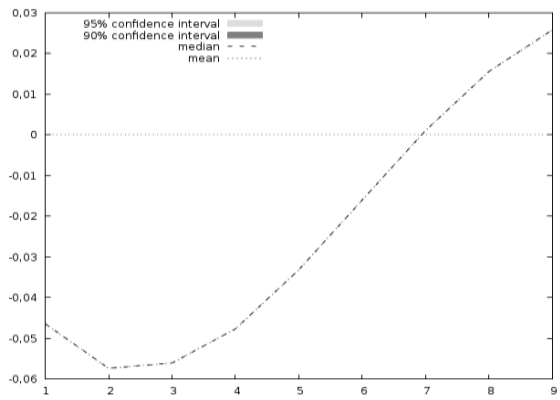

Figure 3. Bootstrap forecasts of threshold variables and business cycle

Note: Mean and median are shown. $90 \%$ and $95 \%$ confidence intervals are shadowed. A vertical line on figures placed on the LHS of the table separates the sample and forecasting period. All the figures have been prepared in Gretl package: Threshold_Models. 


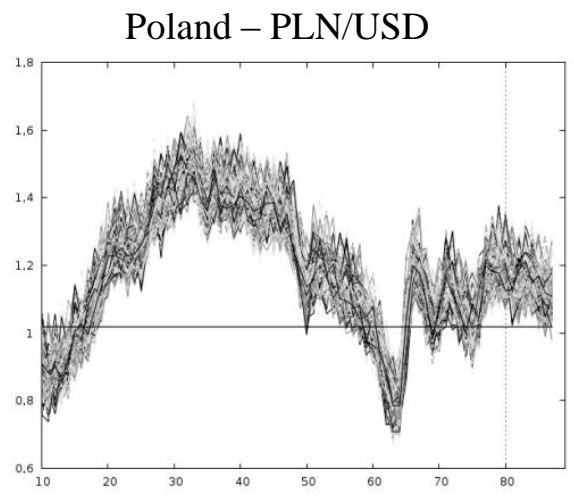

Slovenia - CPI

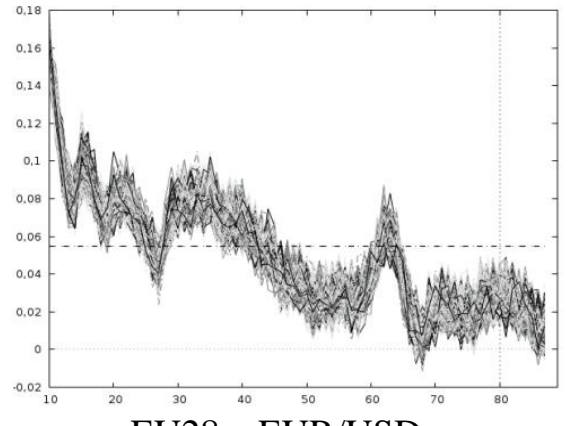

EU28 - EUR/USD

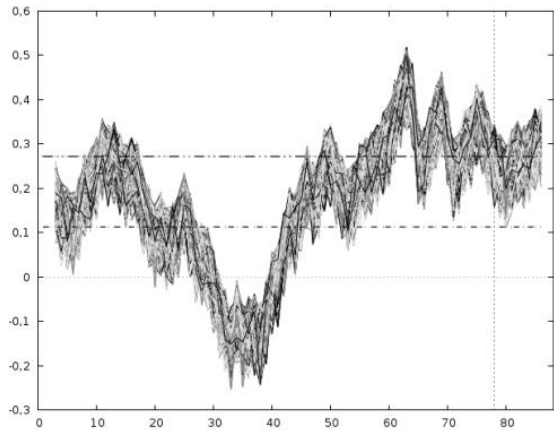

Poland - bootstrap forecast

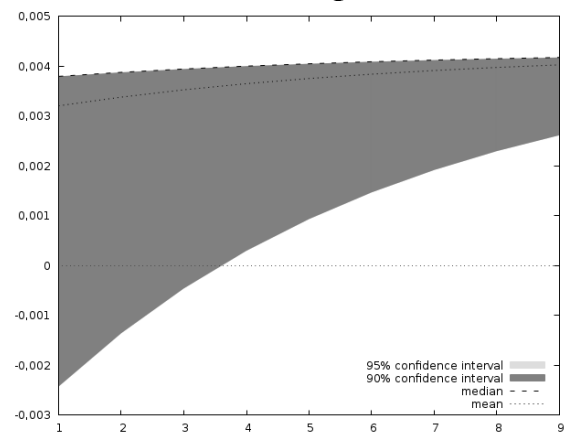

Slovenia - bootstrap forecast

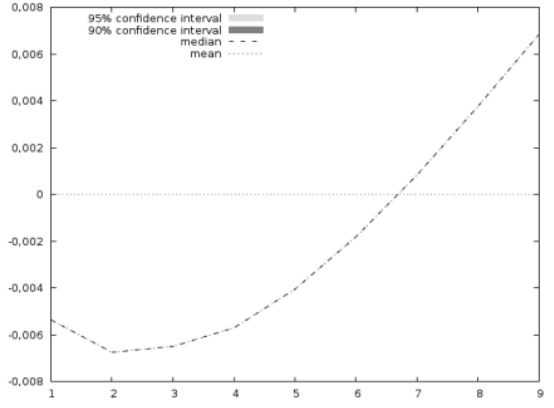

EU28 - bootstrap forecast

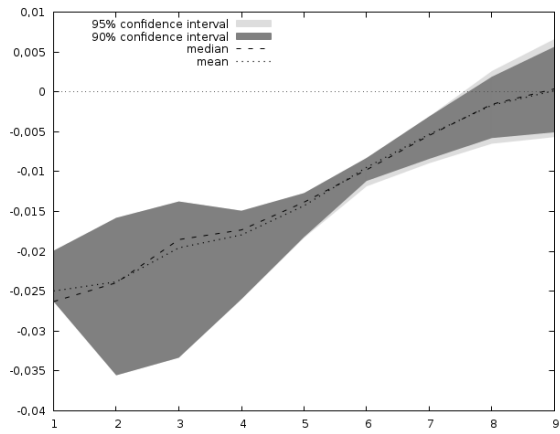

Figure 3. Continued

Note: Mean and median are shown. $90 \%$ and $95 \%$ confidence intervals are shadowed. A vertical line on figures placed on the LHS of the table separates the sample and forecasting period. All the figures have been prepared in Gretl package: Threshold_Models.

It can easily be noted that the results of forecasting a business cycle using a threshold autoregression (TAR) model strongly depends on the results of forecasting the threshold variable. A proper selection of the regime is of 
particular importance. If the threshold tends to penetrate into one regime, the forecast seems to be more precise and the confidence intervals are narrower. In the opposite case, when the threshold is expected to penetrate two or more regimes, the difference between a mean and a median and the confidence interval limits are greater. In the abovementioned cases, the following conclusions can be made:

1. For Estonia - a short interest rate, Hungary - HUF/USD and Slovenia CPI the threshold variables penetrate only one regime in the forecasted period.

2. For Poland, the exchange rate of PLN/USD penetrates one regime, apart from three values that fall into the second one.

3. For the Czech Republic where $\triangle$ CPI and EU28 - EUR/USD the ratio of values that penetrate two regimes, is almost the same.

Empirical results of forecasting quarterly GDP growth rates in selected economies on the basis of TAR models using a simulation approach, revealed different possible paths. For such economies as the Czech Republic, Estonia, the European Union (UE28) (and the Eurozone EU19), the forecasts form the characteristic plume or ribbons. For Poland, the majority of realizations of simulation-based forecasts hit just one possible path and only in a few iterations different results were obtained. Finally, for Hungary and Slovenia, all 1,000 forecast values generated in the bootstrap procedure were identical. As concerns the forecasted tendency of business cycle in 5 cases, the phase of recovery has been indicated. Only in the case of Estonia a slowdown has been shown.

\section{Conclusions}

In 1995-2014, the CEE as well as all the EU economies experienced a business cycle. Its amplitude and phase were diversified among the countries but in general, they were similar. In 2007-2009, the economies were exposed to the global financial and economic recession. Thereafter, economic development divergence processes started. The recession revealed complicated economic and social situations in many countries. At the time of their accession to the EU, CEE countries optimistically developed their economies. They lowered inflation, improved the economic efficiency and developed many economic institutions. Slovenia and Estonia became the leaders of institutional changes in Central European countries. At present, some of the CEE countries are facing a different problem, namely, how to avoid the middle-income trap and how to improve their competitiveness. 
In this paper, we defined and applied a time series-based nonlinear mechanism in the threshold autoregression (TAR) form in order to examine a business cycle in Central and Eastern European economies compared to the entire EU business cycle. Threshold variables, such as consumer price index, short and long interest rates, unemployment rate, exchange rate vs. the U.S. Dollar have been considered. The purpose of the paper was to model and predict business cycles in Central and East European (CEE) economies (the EU Member States) and compare them to the business cycle of the entire EU28 area and Eurozone EU19. We found that the exogenous mechanism played an important role in diagnosing the phases of business cycle in CEE economies, which is in line with the entire EU economic area. The results of business cycles forecasting using bootstrap technique are quite promising, while bootstrap confidence intervals are used for diagnosis.

It is indicated that the results of forecasting a business cycle using a threshold autoregression (TAR) model strongly depends on the results of forecasting the threshold variable. Among the threshold variables, the following were confirmed by the data: the short interest rate (Estonia), HUF/USD (Hungary), CPI (Slovenia), PLN/USD (Poland), $\triangle$ CPI (Czech Republic) and EUR/USD (EU28 and EU19). The proper selection of the regime is of particular importance. If the threshold tends to penetrate into one regime, the forecast seems to be more precise and the confidence intervals are narrower. In the opposite case, when the threshold is expected to enter two or more regimes, the difference between a mean and a median and the confidence interval limits are greater. In 5 cases, business cycle forecasts show a recovery phase. Only in the case of Estonia a slowdown has been predicted.

Although many analyses have been undertaken in the last few years on the monetary and fiscal policy instruments corresponding to different phases of the economic cycle, a proper diagnosis is still an open issue. The quality of institutions, state integrity, the position of the economy (core or peripheral), and the middle-income trap are some examples of states that might affect the economic growth pattern in different countries, including the EU Member States.

\section{References}

An, H., Huang, F. (1996), The Geometrical Ergodicity of Nonlinear Autoregressive Models, Statistica Sinica, 6, 943-956, DOI: http://dx.doi.org/10.1016/0167-7152(94)00082-J.

Barro, R. J., Sala-i-Martin, X. (1992). Convergence. Journal of Political Economy, 100(2), 223-251, DOI: http://dx.doi.org/10.1086/261816. 
Brown B. W., Mariano R. S. (1984), Residual - Based Procedures for Prediction and Estimation in a Nonlinear Simultaneous System, Econometrica, 52, 321-344.

Chan, K. S., Petruccelli, J. D., Tong, H., Woolford, S. W. (1985), A Multiple-threshold AR(1) Model, Journal of Applied Probability, 22(2), 267-279, DOI: http://dx.doi.org/10.1017/S0021900200037748.

Chen, C. W., So, M. K., Liu, F.-C. (2011), A Review of Threshold Time Series Models in Finance, Statistics and its interface, 4(2), 167-181, DOI: http://dx.doi.org/10.4310/SII.2011.v4.n2.a12.

Chen, R., Tsay, R. S. (1991), On the Ergodicity of TAR(1) Processes, The Annals of Applied Probability, 1(4), 613-634, DOI: http://dx.doi.org/10.1214/aoap/1177005841.

Claassen, C., Kabundi, A., Loots E. (2013), Decoupling Between Emerging and Advanced Economies. An Exploratory Analysis, Paper presented at the 11th EBES (Eurasia Business and Economics Society) Conference, Ekaterinburg.

Durlauf, S. N., Johnson, P. A., Temple, J. R. (2005), Growth Econometrics in Aghion, P. Durlauf, S. (ed.), Handbook of Economic Growth, 555-677, Elsevier.

Dvison, A., Hinkley, D. V., Schechtman, E. (1986), Efficient Bootstrap Simulation, Biometrika, 73(3), 555-566, DOI: http://dx.doi.org/10.2307/2336519.

Eyraud, L., Weber, A. (2013), The Challenge of Debt Reduction During Fiscal Consolidation. IMF Working Paper 13/67, International Monetary Fund.

Funke, M., Niebuhr, A. (2005), Threshold Effects and Regional Economic Growth-Evidence from West Germany, Economic Modelling, 22, 61-80, DOI: http://dx.doi.org/10.1016/j.econmod.2004.05.001.

Gnegne, Y., Jawadi, F. (2013), Boundedness and Nonlinearities in Public Debt Dynamics: A TAR Assessment, Economic Modelling, 34, 154-160, DOI: http://dx.doi.org/10.1257/aer.100.2.573.

Granger, C. W. J., Teräsvirta, T. (1993), Modelling Non-Linear Economic Relationships, OUP Catalogue, Oxford University Press.

Greene, W. H. (1993), Econometric Analysis, Macmillan, New York, 2 edition.

Hamilton, J. D. (1994), Time Series Analysis, vol. 2, Princeton University Press Princeton.

Herndon, T., Ash, M., Pollin, R. (2014), Does High Public Debt Consistently Stifle Economic Growth? A Critique of Reinhart and Rogoff, Cambridge Journal of Economics, 38(2), 257-279, DOI: http://dx.doi.org/10.1093/cje/bet075.

Hodrick, R.J., Prescott, E.C. (1997), Postwar U.S. Business Cycles: An Empirical Investigation, Journal of Money, Credit and Banking, 29(1), 1-16.

Ilzetzki, E. (2011), Fiscal Policy and Debt Dynamics in Developing Countries, Policy Research Working Paper WPS5666, The World Bank Group.

Im, F.G., Rosenblatt, D. (2015), Middle-Income Traps: A Conceptual and Empirical Survey, Journal of International Commerce, Economics and Policy, 6(3), 155-194, DOI: http://dx.doi.org/10.1142/S1793993315500131.

Kapetanios, G., Shin, Y. (2006), Unit Root Tests in Three-regime SETAR Model, Econometrics Journal, 9(2), 252-278, DOI: http://dx.doi.org/10.1111/j.1368-423X.2006.00184.x.

Kawa, P. (2011), Wplyw zaburzeń na rynkach finansowych na wzrost gospodarczy $w$ krajach na średnim poziomie rozwoju (TheIimpact of Financial Turmoil on Economic Growth in the Countries the Average Level of Development) in Wojtyna, A. (ed.) Kryzys finansowy i jego skutki dla krajów na średnim poziomie rozwoju. PWE.

Kluth, K., (2016), Statystyczna i ekonometryczna analiza konwergencji gospodarczej i spotecznej państw Unii Europejskiej (Statistical and Econometric Analysis of Economic and Social Convergence EU Countries), Wyd. UMK, Toruń, forthcoming.

Dynamic Econometric Models 16 (2016) 145-164 
Kourtellos, A., Stengos, T., Tan, C. M. (2013), The Effect of Public Debt on Growth in Multiple Regimes, Journal of Macroeconomics, 38, 35-43, DOI: http://dx.doi.org/10.1016/j.jmacro.2013.08.023.

Kremer, S., Bick, A., Nautz, D. (2013). Inflation and Growth: New Evidence from a Dynamic Panel Threshold Analysis, Empirical Economics, 44(2), 861-878, DOI: http://dx.doi.org/10.1007/s00181-012-0553-9.

Krugman, P. (2012), End This Depression Now! WW Norton \& Company.

Ling, S. (1999), On the Probabilistic Properties of a Double Threshold ARMA Conditional Heteroskedastic Model. Journal of Applied Probability, 36(3), 688-705, DOI: http://dx.doi.org/10.1239/jap/1032374627.

Mendieta-Muñoz, I. (2016), On the Interaction Between Economic Growth and Business Cycles, Macroeconomic Dynamics, 1, 1-41, DOI: http://dx.doi.org/10.1017/S1365100515000796.

Misztal, P. (2011), Dług publiczny i wzrost gospodarczy w krajach członkowskich unii europejskiej, Zeszyty Naukowe Szkoty Głównej Gospodarstwa Wiejskiego w Warszawie. Polityki Europejskie, Finanse i Marketing 5(54), 101-114.

Mota, P. R., Fernandes, A. L. C., Nicolescu, A.-C. (2012), The Recent Dynamics of Public Debt in the European Union: A Matter of Fundamentals or the Result of a Failed Monetary Experiment? FEP Working Papers 467, Universidade do Porto, Faculdade de Economia do Porto.

Niglio, M., Giordano, F., Vitale, C. D. (2012), On the Stationarity of the Threshold Autoregressive Process: the Two Regimes Case in Giommi, A. (ed.) 46TH SCIENTIFIC MEETING OF THE ITALIAN STATISTICAL SOCIETY.

Osińska, M., Kluth, K. (2011), Konwergencja gospodarcza krajów Europy Środkowowschodniej do poziomu UE w latach 1995-2009 (Economic Convergence of Central and East European Countries to the EU Level in 1995-2009), Zeszyty Naukowe WSG w Bydgoszczy Ekonomia, 3, 141-150.

Osińska, M., Kufel, T., Blazejowski, M., Kufel, P. (2015), Zegar cyklu koniunkturalnego państw UE i USA w latach 1995-2013 w świetle badań synchronizacji, (Business Cycle Clock for the EU and the USA in 1995-2013 in the Light of Synchronization Research), Prace Naukowe Uniwersytetu Ekonomicznego we Wrocławiu, Taksonomia, 25, 138-146, DOI: http://dx.doi.org/10.15611/pn.2015.385.15.

Osińska, M., Kufel, T., Blazejowski, M., Kufel, P. (2016a), Business Cycle Synchronization in Eu Economies After the Recession of the years 2007-2009, Argumenta Oeceonomica, 2(37), DOI: http://dx.doi.org/10.15611/aoe.2016.2.01.

Osińska, M., Kufel, T., Blazejowski, M., Kufel, P. (2016b), Does Economic Growth Really Depend on the Magnitude of Debt? A Threshold Model Approach, University Library of Munich, MPRA Paper, 71476.

Petruccelli, J. D., Woolford, S. W. (1984). A Threshold AR(1) Model, Journal of Applied Probability, 21(2), 270-286, DOI: http://dx.doi.org/10.1017/S0021900200024670.

Rubinstein, R. Y., Kroese, D. P. (2011), Simulation and the Monte Carlo Method, John Wiley \& Sons.

Saleh, A. S., Harvie, C. (2005). The Budget Deficit and Economic Performance: a Survey, The Singapore Economic Review, 50(02), 211-243, DOI: http://dx.doi.org/10.1142/S0217590805001986.

Schclarek, A. (2005), Debt and Economic Growth in Developing and Industrial Countries. Working Papers 2005:34, Lund University, Department of Economics.

Spence, M. (2011), The Next Convergence. The Future of Economic Growth in a Multispeed World, New York: Farrar, Straus and Giroux. 
Stańczyk, Z., Wyrobek, J. (2013), Zastosowanie analizy spektralnej do weryfikacji hipotezy o rozłączeniu się gospodarek rozwiniętych i wschodzących (Spectral Analysis-based Verification of the Decoupling Hypothesis between Developed and Emerging Economies), Zeszyty Naukowe Uniwersytetu Ekonomicznego w Krakowie, 920, 5-21.

Tong, H. (1990), Non-Linear Time Series: A Dynamical System Approach, Oxford University Press, Oxford.

Tong, H. (2007). Birth of the Threshold Time Series Model, Statistica Sinica, 17(1), 8-14, DOI: http://dx.doi.org/10.1142/9789812836281_0001.

Tong, H. (2011), Threshold Models in Time Series Analysis-30 Years on, Statistics and its Interface, 4(2), 107-118, DOI: http://dx.doi.org/10.4310/SII.2011.v4.n2.a1.

Zarnowitz, V. (1999), Theory and History Behind Business Cycles: Are the 1990s the Onset of a Golden Age? Journal of Economic Perspectives, 13(2), 69-90, DOI: http://dx.doi.org/10.1257/jep.13.2.69.

\section{Modelowanie i prognozowanie cyklu koniunkturalnego w krajach Europy Środkowej i Wschodniej za pomocą podejścia progowego}

Z a r y s tre ś c i : Artykuł przedstawia badanie cykli koniunkturalnych gospodarek państw Europy Środkowej i Wschodniej w porównaniu do gospodarki Unii Europejskiej przy wykorzystaniu nieliniowego podejścia - modeli progowych (TAR). Rozważanymi zmiennymi progowymi są: stopa inflacji, krótko i długoterminowa stopa procentowa, stopa bezrobocia oraz kurs walutowy do dolara. Celem artykułu jest modelowanie oraz prognozowanie cyklu koniunkturalnego w państwach Europy Środkowej i Wschodniej oraz porównanie ich do cykli dla całej Unii Europejskiej oraz strefy Euro. Prognozowanie cyklu koniunkturalnego za pomocą technik bootstrapowych daje obiecujące wyniki, szczególnie gdy wykorzystywane są bootstrapowe przedziały ufności.

S ł o w a k l u c z o w e: cykl koniunkturalny, business cycle, central and eastern economies, threshold models, forecasting, bootstrap. 